Prepared in cooperation with the U.S. Centers for Disease Control and Prevention and the Maine Center for Disease Control and Prevention

\title{
Methods of Collection and Quality Assessment of Arsenic Data in Well-Water Supplies in Maine, 2001-2 and 2006-7
}

Data Series 1125 



\section{Methods of Collection and Quality Assessment of Arsenic Data in Well-Water Supplies in Maine, 2001-2 and 2006-7}

By Charles W. Culbertson, James M. Caldwell, Luther F. Schalk,

Deana Manassaram, Lorraine C. Backer, and Andrew E. Smith

Prepared in cooperation with the U.S. Centers for Disease Control and

Prevention and the Maine Center for Disease Control and Prevention

Data Series 1125 


\title{
U.S. Department of the Interior \\ DAVID BERNHARDT, Secretary
}

\author{
U.S. Geological Survey \\ James F. Reilly II, Director
}

U.S. Geological Survey, Reston, Virginia: 2020

For more information on the USGS - the Federal source for science about the Earth, its natural and living resources, natural hazards, and the environment—visit https://www.usgs.gov or call 1-888-ASK-USGS.

For an overview of USGS information products, including maps, imagery, and publications, visit https://store.usgs.gov/.

Any use of trade, firm, or product names is for descriptive purposes only and does not imply endorsement by the U.S. Government.

Although this information product, for the most part, is in the public domain, it also may contain copyrighted materials as noted in the text. Permission to reproduce copyrighted items must be secured from the copyright owner.

Suggested citation:

Culbertson, C.W., Caldwell, J.M., Schalk, L.F., Manassaram, D., Backer, L.C., and Smith, A.E., 2020, Methods of collection and quality assessment of arsenic data in well-water supplies in Maine, 2001-2 and 2006-7:

U.S. Geological Survey Data Series 1125, 11 p., https://doi.org/10.3133/ds1125.

Associated data for this publication:

Culbertson, C.W., Caldwell, J.M., Schalk, L.F., and Medalie, L., 2020, Arsenic datasets and other physical and chemical measurements for selected domestic well-water supplies in Maine-2001-2 and 2006-7:

U.S. Geological Survey data release, https://doi.org/10.5066/P9X5HVDF.

ISSN 2327-638X (online) 


\section{Contents}

Abstract

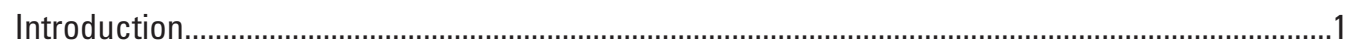

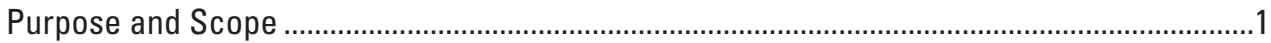

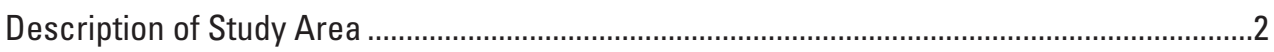

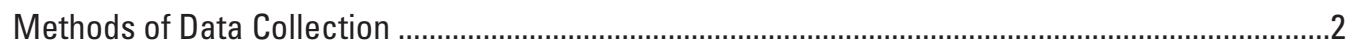

Measurement of Field Water-Quality Constituents ................................................................2

Sample Collection for Well-Water Chemical Analyses Performed in the Field ........................2

Point-of-Entry and Point-of-Use Sample Collection for Laboratory Chemical

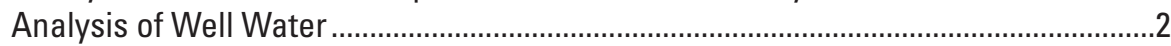

Point-of-Entry and Point-of-Use Sample Collection for Laboratory Arsenic and

Arsenic Speciation (Valence) Analysis .........................................................................

Arsenic Sample Preparation and Preservation ...........................................................................8

Preparation of Field Anion-Exchange Chromatography Columns for Arsenic

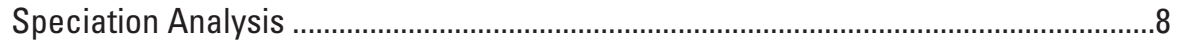

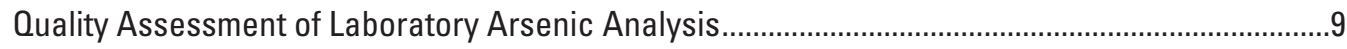

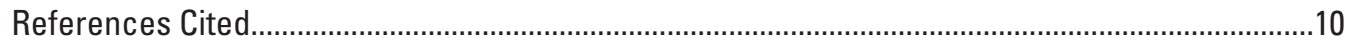

\section{Figures}

1. Map showing domestic-well sample locations in Maine, 2001-2 and 2006-7..................3

2. Boxplots showing distribution of unfiltered arsenic concentrations in paired samples analyzed by the Maine Department of Human Services Health and Environmental Testing Laboratory (HETL) and Underwriters Laboratories Inc. (UL), 2006-7

3. Graph showing arsenic concentrations in paired samples analyzed by the Maine Department of Human Services Health and Environmental Testing Laboratory and Underwriters Laboratories Inc., 2006-7.

\section{Tables}

1. Method information, minimum reporting limits, and U.S. Geological Survey National Water Information System parameter codes for all constituents measured in water samples collected from domestic wells in Maine for laboratory analyses, 2001-2 and 2006-7

2. Constituents, U.S. Geological Survey National Water Information System parameter codes, minimum reporting limits, and method information for all water samples collected from domestic wells in Maine for analyses performed in the field, 2001-2 and 2006-7

3. Constituents, field parameters, arsenic speciation, and measuring entities for water samples collected from domestic wells in Maine, 2001-2 and 2006-7...

4. Representative efficiency of anion-exchange chromatography resin for the field separation of $\mathrm{As}(\mathrm{III})$ and $\mathrm{As}(\mathrm{V})$ for single arsenic species recovery

5. Representative efficiency of anion-exchange chromatography resin for the field separation of $\mathrm{As}(\mathrm{III})$ and $\mathrm{As}(\mathrm{V})$ for $\mathrm{As}(\mathrm{III})+\mathrm{As}(\mathrm{V})$ mix recovery. 


\section{Conversion Factors}

International System of Units to U.S. customary units

\begin{tabular}{lll}
\hline \multicolumn{1}{c}{ Multiply } & \multicolumn{1}{c}{ By } & \multicolumn{1}{c}{ To obtain } \\
\hline micrometer $(\mu \mathrm{m})$ & Length & \\
centimeter $(\mathrm{cm})$ & 0.00003937 & inch (in.) \\
meter $(\mathrm{m})$ & 0.3937 & inch (in.) \\
kilometer $(\mathrm{km})$ & 3.281 & foot (ft) \\
& 0.6214 & mile (mi) \\
cubic meter $\left(\mathrm{m}^{3}\right)$ & Volume & \\
milliliter $(\mathrm{mL})$ & 6.290 & barrel (petroleum, 1 barrel = 42 gal) \\
& 0.03381 & ounce, fluid (fl. oz) \\
liter per second $(\mathrm{L} / \mathrm{s})$ & Flow rate & \\
& 15.85 & gallon per minute (gal $/ \mathrm{min})$ \\
milligram $(\mathrm{mg})$ & Mass & \\
kilogram $(\mathrm{kg})$ & 0.00003527 & ounce, avoirdupois (oz) \\
\hline
\end{tabular}

Temperature in degrees Celsius $\left({ }^{\circ} \mathrm{C}\right)$ may be converted to degrees Fahrenheit $\left({ }^{\circ} \mathrm{F}\right)$ as ${ }^{\circ} \mathrm{F}=\left(1.8 \times{ }^{\circ} \mathrm{C}\right)+32$.

\section{Datum}

Horizontal coordinate information is referenced to the North American Datum of 1983 (NAD 83).

\section{Supplemental Information}

Specific conductance is given in microsiemens per centimeter at 25 degrees Celsius $(\mu \mathrm{S} / \mathrm{cm}$ at $\left.25^{\circ} \mathrm{C}\right)$.

Concentrations of chemical constituents in water are given in milligrams per liter $(\mathrm{mg} / \mathrm{L})$ or micrograms per liter ( $\mu \mathrm{g} / \mathrm{L})$.

Turbidity is reported in nephelometric turbidity units (NTU).

Concentrations of bacteria are reported in colony forming units per 100 milliliters (CFU/100 mL). 


\section{Abbreviations}

EPA U.S. Environmental Protection Agency

HETL Health and Environmental Testing Laboratory, Maine Department of Human Services

NWOL National Water Quality Laboratory

POE point of entry

POU point of use

$\mathrm{OA} / \mathrm{OC}$ quality assurance and quality control

UL Underwriters Laboratories Inc.

USGS U.S. Geological Survey 



\title{
Methods of Collection and Quality Assessment of Arsenic Data in Well-Water Supplies in Maine, 2001-2 and 2006-7
}

\author{
By Charles W. Culbertson,1 James M. Caldwell,1 Luther F. Schalk,1 Deana Manassaram,2 Lorraine C. Backer, ${ }^{2}$ \\ and Andrew E. Smith 3
}

\section{Abstract}

The U.S. Geological Survey, in cooperation with the U.S. Centers for Disease Control and Prevention and the Maine Center for Disease Control and Prevention, assessed the chemical characteristics and the occurrence, distribution, and oxidation state of inorganic arsenic in drinking water from selected domestic well-water supplies in Maine in 2001-2 and 2006-7.

The data collected provide support for evaluating arsenicremoval efficiencies of household water-purification systems and provide information to State and local officials that can be used in determining a water-treatment approach for the removal of arsenic from drinking water.

\section{Introduction}

Arsenic is toxic to humans and widespread in surface water and groundwater throughout the United States and world (National Research Council, 1999; Welch and others, 1999; Welch and others, 2000; Focazio and others, 2000; Ryker, 2001; Smedley and Kinniburgh, 2002; DeSimone and others, 2009). Arsenic in surface waters and groundwater aquifers has both anthropogenic and natural sources. Anthropogenic sources include current and historical industrial uses, as well as broad-spectrum uses in the lumber, agriculture, and livestock industries (National Research Council, 2001). Arsenic occurs naturally in the Earth's crust, ranking as the 20th most abundant element, with an average crustal abundance of approximately 2 milligrams per kilogram (0.0002 percent). It is common in weathered volcanic and marine sedimentary rocks containing iron and manganese oxides, in fossil fuels, and in a number of minerals, including arsenopyrite (FeAsS), orpiment $\left(\mathrm{As}_{2} \mathrm{~S}_{3}\right)$, scorodite $\left(\mathrm{FeAsO}_{4}\right)$, and realgar (AsS) (Cullen and Reimer, 1989; Korte and Fernando, 1991; Smedley and Kinniburgh, 2002).

\footnotetext{
${ }^{1}$ U.S. Geological Survey.

2U.S. Centers for Disease Control and Prevention.

${ }^{3}$ Maine Department of Health and Human Services.
}

Arsenic in groundwater is primarily inorganic, either in the oxidized state as arsenate $[\mathrm{As}(\mathrm{V})]$, the form typical in oxic waters, or the reduced state as arsenite [As(III)], the form typical in anoxic waters (Cullen and Reimer, 1989; Smedley and Kinniburgh, 2002).

Roughly half of the population of Maine derives its drinking water from domestic wells, of which about 75 percent are drilled bedrock wells. Arsenic concentrations above the current U.S. Environmental Protection Agency (EPA) drinking-water standard of 10 micrograms per liter $(\mu \mathrm{g} / \mathrm{L}$ or parts per billion) (U.S. Environmental Protection Agency, 2001) have been detected in water from drilled bedrock wells throughout Maine (Marvinney and others, 1994, 1995; Peters and others, 1999; Ayotte and others, 1999, 2003, 2006; Lipfert and others, 2006; Yang and others, 2009; Nielsen and others, 2010; Zheng and Ayotte, 2015; Flanagan and others, 2012). Effective removal of arsenic by household water-purification systems is constrained by the chemical form (for example, oxidation state) in which it occurs, as well as the prevailing chemical characteristics of the well water, including $\mathrm{pH}$, and the presence of competing ions, such as phosphate (U.S. Environmental Protection Agency, 2001).

The U.S. Geological Survey (USGS), in cooperation with the U.S. Centers for Disease Control and Prevention and the Maine Center for Disease Control and Prevention, assessed the chemical characteristics and the occurrence, distribution, and oxidation state of inorganic arsenic in drinking water from selected domestic well-water supplies in Maine in 2001-2 and 2006-7.

The data collected provide support for evaluating arsenicremoval efficiencies of household water-purification systems and provide information to State and local officials that can be used in determining a water-treatment approach for the removal of arsenic from drinking water.

\section{Purpose and Scope}

This report describes methods used to collect arsenic and other water-chemistry data from domestic well water in support of studies evaluating arsenic removal efficiencies of household water purification systems. Data consist of water-chemistry results from samples collected over two time periods: 2001-2 and 2006-7 (also two samples collected 
in 2008), well characteristics (depth and type), and chemical characteristics of well water from approximately 120 selected domestic wells in known high-arsenic clusters throughout the State of Maine. All data are available in the USGS National Water Information System (NWIS) database, are searchable by USGS site number (U.S. Geological Survey, 2019), and are published in Culbertson and others (2020).

\section{Description of Study Area}

The study area includes most of the populated areas in the State of Maine apart from Aroostook County in northeastern Maine. The samples collected were from singlefamily dwellings relying on private well water as the primary drinking-water supply; additionally, these households had water-purification systems designed for the removal of arsenic installed either at the well-water point of entry (POE) or point of use (POU). The initial pilot study included 31 households sampled for arsenic and arsenic species in 2001-2, whereas the full-scale study included 120 households sampled in 2006-7. Households were recruited based on their locations in areas of Maine known to have high concentrations of arsenic $(>10 \mu \mathrm{g} / \mathrm{L}$ ) in groundwater (fig. 1).

\section{Methods of Data Collection}

Households with domestic wells included in this study were identified and prescreened prior to both sampling periods by project personnel associated with concurrent studies by the U.S. Centers for Disease Control and Prevention and the Maine Center for Disease Control and Prevention. To be considered for the study, households needed to have well water containing elevated $(>10 \mu \mathrm{g} / \mathrm{L})$ concentrations of arsenic and a previously installed water-purification system designed to remove arsenic; systems used reverse-osmosis, anionexchange, or adsorption technologies. Most homes tested had point-of-use reverse-osmosis systems installed. Well-water samples (pre-water-treatment system) were collected at the house POE, prior to the pressure tank and household watertreatment system(s), by using the existing domestic well-water pump. Samples collected after water treatment were collected at the kitchen (POU) faucet. A list of constituent names, USGS NWIS parameter codes, and minimum reporting limits for all samples collected for laboratory and field analyses are shown in tables 1 and 2. A summary of field measurements and analytical determinations, along with the entity or entities that analyzed or measured each, is presented in table 3.

\section{Measurement of Field Water-Quality Constituents}

Prior to collection of POE well water for arsenic and other chemical analyses, field measurements of temperature, specific conductance, $\mathrm{pH}$, and dissolved oxygen were measured onsite using a multiparameter water-quality monitor immersed in a flow-through chamber under a steady water flow of approximately $1-1.5$ liters per minute. Field measurements and water-chemistry results are published in Culbertson and others (2020). During the 2006-7 sample collection period, low dissolved oxygen readings $(<1 \mathrm{mg} / \mathrm{L})$ were confirmed by an alternate, colorimetric method (CHEMets colorimetric dissolved oxygen test kit, 0-1 part per million; CHEMetrics, Inc., Calverton, Va.). Samples for water chemistry determinations and arsenic analyses were collected after water-quality-monitor readings had stabilized (generally $0.25-0.75$ hour). Except for specific conductance, field measurements of the other water-quality constituents in POU water samples were not made because of physical and chemical alterations imparted by the water-treatment systems. Specific conductance, a proxy for total dissolved solids, was measured in both prefiltration and postfiltration water, specifically to assess the performance efficiencies of reverse-osmosis water-treatment systems in removing arsenic (Fravel and Lindsey, 2014).

\section{Sample Collection for Well-Water Chemical Analyses Performed in the Field}

Upon obtaining stabilized readings of temperature, specific conductance, and $\mathrm{pH}$, well-water samples for field chemical analyses were collected. Field measurements (or analyses) of POE well water included total iron, ferrous iron (FeII), total manganese, reactive phosphorus, sulfate, sulfide, and nitrate. These measurements were made immediately upon sample collection using standard colorimetric methods (American Public Health Association, 1998; Hach Company, 2000). Equipment blanks and sample replicates for quality-control (QC) purposes were collected and analyzed with the field samples. Additionally, during the 2006-7 sample collection period, replicate samples for some constituents were collected for chemical analysis by an alternate laboratory and method (Underwriters Laboratories Inc. [UL], South Bend, Indiana). Results of field chemical and quality-control analyses are published in Culbertson and others (2020).

\section{Point-of-Entry and Point-of-Use Sample Collection for Laboratory Chemical Analysis of Well Water}

According to study protocols for the 2006-7 study, two laboratories (Underwriters Laboratories Inc. [UL], South Bend, Indiana, and the Health and Environmental Testing Laboratory [HETL] of the Maine Department of Human Services ${ }^{4}$ in Augusta, Maine) were used to measure arsenic concentrations. The laboratory results from these two facilities are published here as a means of comparison of the analytical

\footnotetext{
${ }^{4}$ Since July 2004, the Maine Department of Health and Human Services.
} 


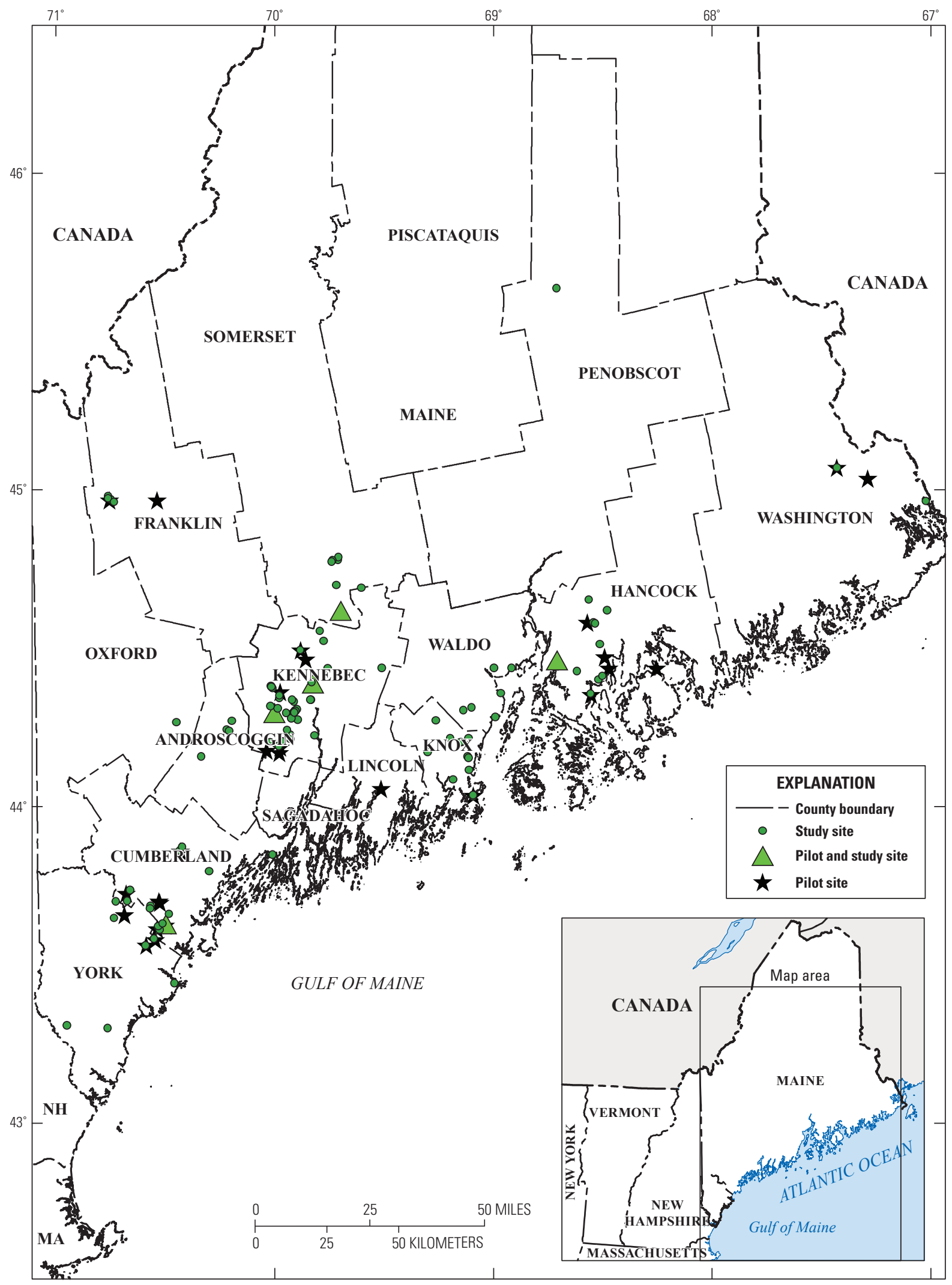

Figure 1. Domestic-well sample locations in Maine, 2001-2 and 2006-7. 


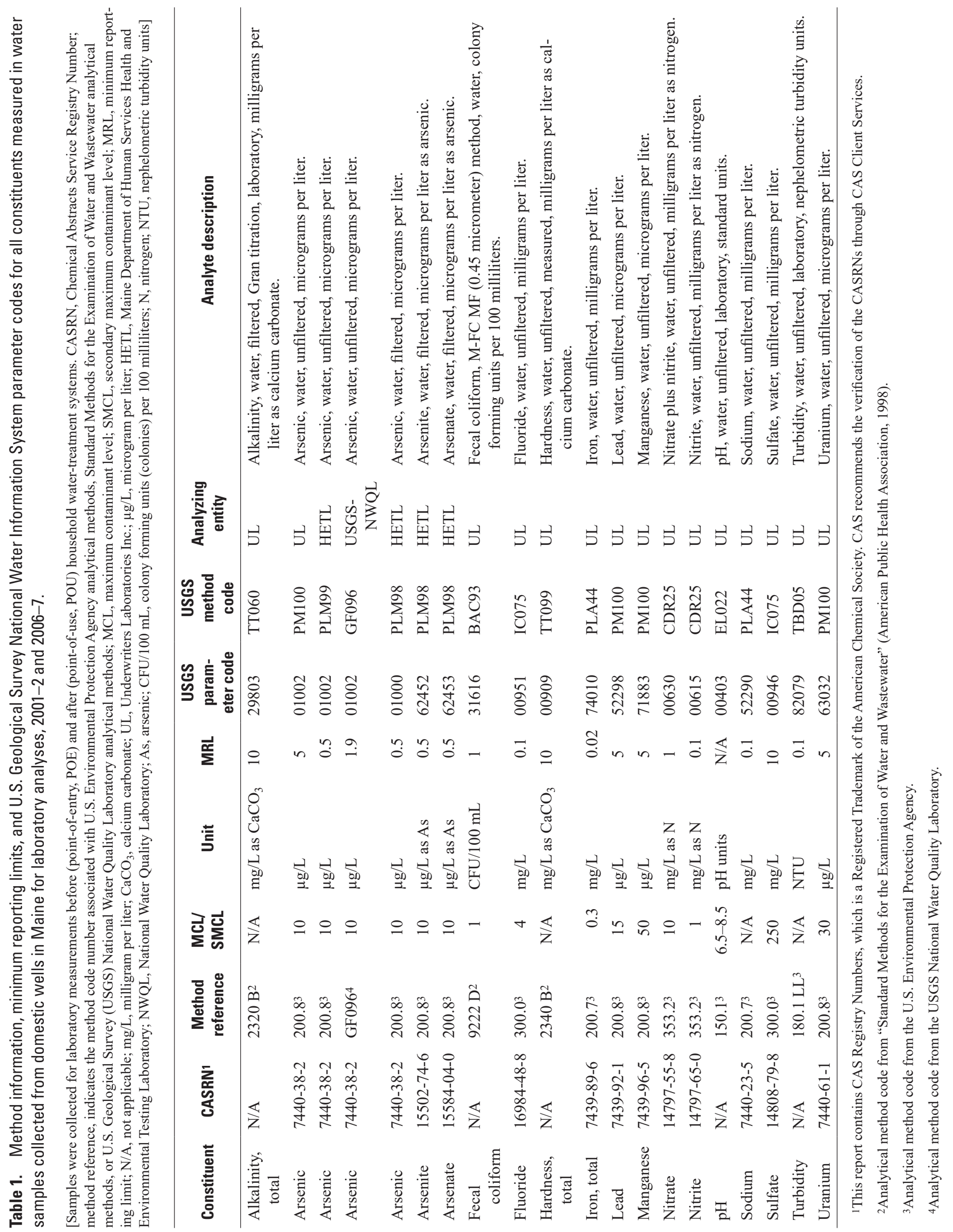




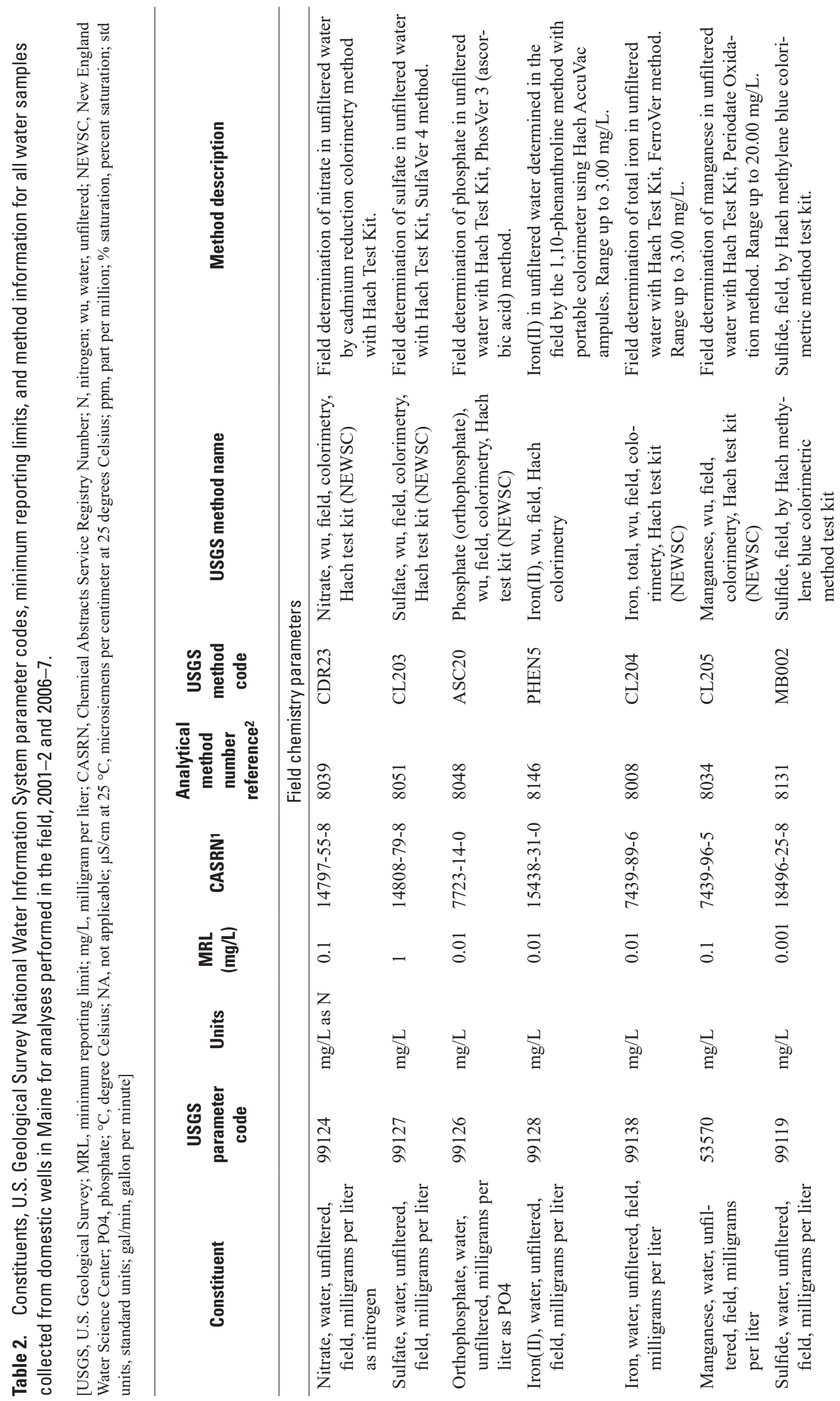




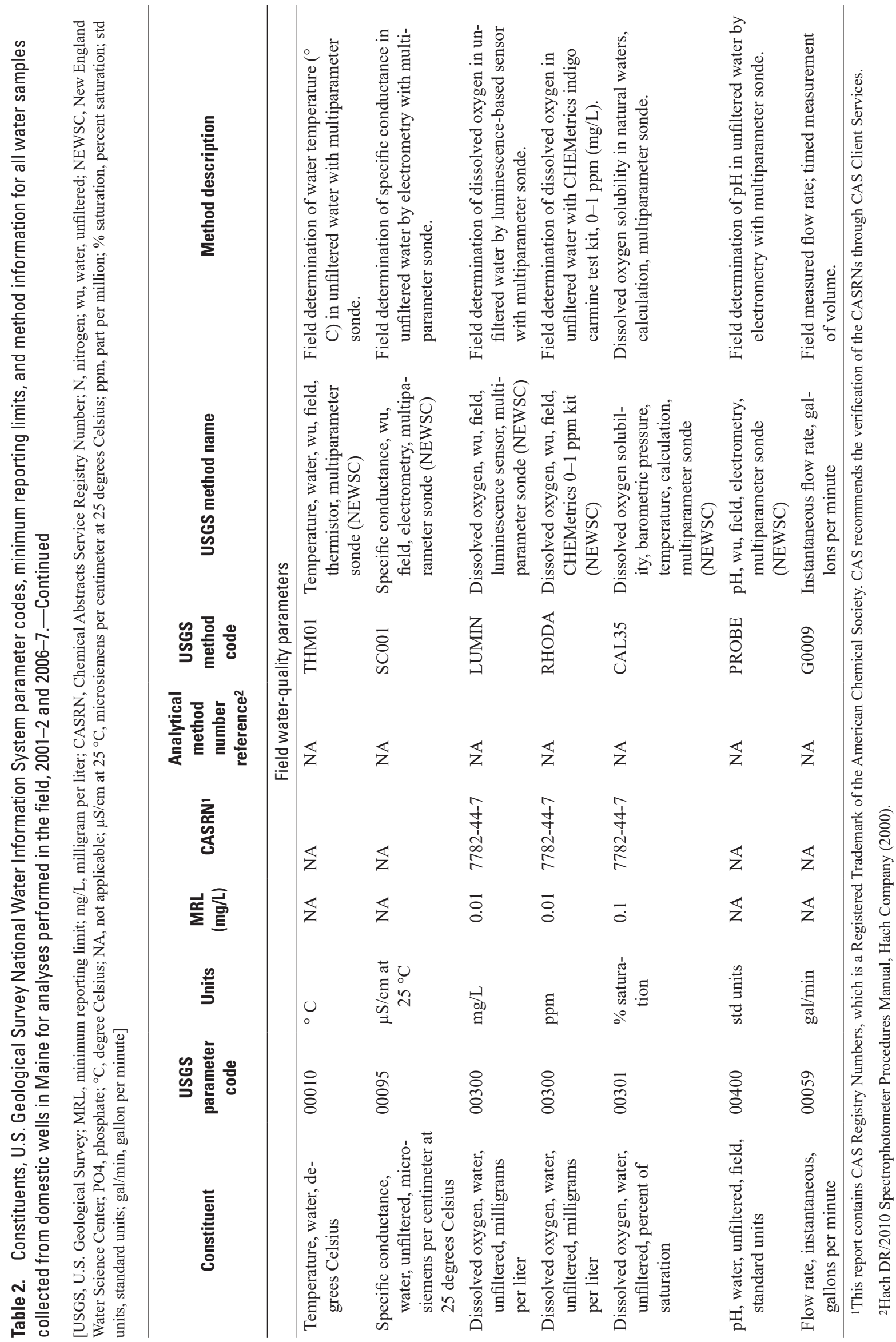


Table 3. Constituents, field parameters, arsenic speciation, and measuring entities for water samples collected from domestic wells in Maine, 2001-2 and 2006-7.

[USGS, U.S. Geological Survey; Maine HETL, Maine Department of Human Services Health and Environmental Testing Laboratory, Augusta, Maine; Underwriters Laboratories, Underwriters Laboratories Inc., South Bend, Indiana; NWQL, National Water Quality Laboratory, Denver, Colorado; DO, dissolved oxygen]

\begin{tabular}{|c|c|c|c|c|c|}
\hline \multirow[b]{2}{*}{ Constituent } & \multirow[b]{2}{*}{$\begin{array}{c}\text { USGS } \\
\text { parameter } \\
\text { code }\end{array}$} & \multicolumn{4}{|c|}{ Laboratory or measuring entity } \\
\hline & & $\begin{array}{l}\text { Maine HETL } \\
2001-2 ; \\
2006-7\end{array}$ & $\begin{array}{c}\text { Underwriters } \\
\text { Laboratories } \\
2006-7\end{array}$ & $\begin{array}{l}\text { USGS- } \\
\text { NWOL } \\
2001-2\end{array}$ & $\begin{array}{l}\text { USGS field } \\
\text { measurements } \\
\text { 2001-2; 2006-7 }\end{array}$ \\
\hline \multicolumn{6}{|c|}{ Analytical determinations } \\
\hline Alkalinity & 29803 & & $\mathrm{X}$ & & \\
\hline Arsenic, total (unfiltered) & 01002 & $\mathrm{X}$ & $X$ & $\mathrm{X}$ & \\
\hline Arsenic, dissolved (filtered) & 01000 & $\mathrm{X}$ & & & \\
\hline Fecal coliform & 31616 & & $\mathrm{X}$ & & \\
\hline Fluoride & 00951 & & $\mathrm{X}$ & & \\
\hline Iron, total & $74010 / 99138$ & & $\mathrm{X}$ & & $\mathrm{X}$ \\
\hline Iron, ferrous (Fe II) & 99128 & & & & $\mathrm{X}$ \\
\hline Iron, ferric (Fe III) & 51279 & & & & $\mathrm{X}$ \\
\hline Lead & 52298 & & $\mathrm{X}$ & & \\
\hline Manganese & $71883 / 53570$ & & $\mathrm{x}$ & & $\mathrm{X}$ \\
\hline Nitrate & 00630/99124 & & $\mathrm{X}$ & & $\mathrm{X}$ \\
\hline Nitrite & 00615 & & $\mathrm{X}$ & & \\
\hline pH (lab) & 00403 & & $\mathrm{X}$ & & \\
\hline Phosphate & 99126 & & & & $\mathrm{X}$ \\
\hline Sodium & 52290 & & $\mathrm{X}$ & & \\
\hline Sulfate & 00946/99127 & & $\mathrm{X}$ & & $\mathrm{X}$ \\
\hline Sulfide & 99119 & & & & $\mathrm{X}$ \\
\hline Total hardness & 00909 & & $\mathrm{X}$ & & \\
\hline Turbidity & 82079 & & $\mathrm{X}$ & & \\
\hline Uranium & 63032 & & $\mathrm{X}$ & & \\
\hline \multicolumn{6}{|c|}{ Field parameters } \\
\hline Dissolved oxygen & 00300 & & & & $\mathrm{X}$ \\
\hline Percent DO saturation & 00301 & & & & $\mathrm{X}$ \\
\hline pH (field) & 00400 & & & & $\mathrm{X}$ \\
\hline Specific conductance & 00095 & & & & $\mathrm{X}$ \\
\hline Temperature & 00010 & & & & $\mathrm{X}$ \\
\hline \multicolumn{6}{|c|}{ Arsenic speciation—field preparation } \\
\hline Total arsenic, raw well water & & & & & $\mathrm{X}$ \\
\hline Filtered arsenic, raw well water & & & & & $\mathrm{X}$ \\
\hline Arsenite $[\mathrm{As}(\mathrm{III})]$, raw well water; field ion exchange & & & & & $\mathrm{X}$ \\
\hline Arsenate $[\operatorname{As}(V)]$, raw well water; field ion exchange & & & & & $\mathrm{X}$ \\
\hline Filtered arsenic, well water, post-household filtration system & & & & & $\mathrm{X}$ \\
\hline Arsenite [As(III)], well water, post-household filtration system & & & & & $\mathrm{X}$ \\
\hline
\end{tabular}


results for many of the same constituents, and to help inform the evaluation of the water treatment system performance in both studies.

POE and POU samples were collected for laboratory chemical analysis by following standard USGS protocols (U.S. Geological Survey, variously dated) and that of the Underwriters Laboratories Inc. (UL) DrinkWell well-water testing system. Once stable readings for temperature, specific conductance, and $\mathrm{pH}$ were achieved ( $0.25-0.75$ hour), POE samples were collected. Source water for POU samples (kitchen faucet) was run continuously for approximately 20 minutes prior to sample collection. The faucet aerator on the POU faucet was removed to minimize sample aeration. Faucets were disinfected with alcohol (isopropanol) wipes prior to sample collection. Bottle types and preservatives varied depending on the analysis to be performed. A complete list of constituents and minimum reporting limits is shown in table 1. All samples collected for analysis at UL were chilled to 4 degrees Celsius and shipped overnight on the day of collection. Samples were analyzed within appropriate, analytespecific holding times, according to the laboratories' standard operating procedures. Published arsenic results are labeled as either "pre-household filtration" (POE) or "post-household filtration" (POU) samples (Culbertson and others, 2020).

\section{Point-of-Entry and Point-of-Use Sample Collection for Laboratory Arsenic and Arsenic Speciation (Valence) Analysis}

Household well-water samples for unfiltered arsenic, filtered arsenic (0.45- $\mu \mathrm{m}$ filter), and filtered As(III), and $\mathrm{As}(\mathrm{V})$ were collected at the POE and processed onsite prior to laboratory analysis. Laboratory analyses of arsenic, for both the 2001-2 and 2006-7 sampling periods, were performed by the Health and Environmental Testing Laboratory (HETL) of the Maine Department of Human Services 5 in Augusta, Maine, and are published in Culbertson and others (2020). A subset of sample replicates (paired samples) were collected during the 2001-2 sampling period and analyzed by both the HETL and the USGS National Water Quality Laboratory (NWQL). Replicate results are identified as such in Culbertson and others (2020) by the "SampleType" field. In both sampling periods, the effectiveness of household water-treatment systems in removing arsenic was assessed by comparing POU samples (post-arsenic treatment system, collected at the kitchen faucet) to raw, untreated POE samples. Throughout the 2006-7 sampling period, replicate (paired) samples were collected for preand post-arsenic treatment system assessment and analyzed by both UL and HETL. During preliminary stages of the 2006-7 sampling period, post-household treatment system (POU) samples were analyzed for filtered arsenic as well as As(III); however, there was concern that any As(III) present could be oxidized by interaction with the treatment system and thus be

${ }^{5}$ Since July 2004, the Maine Department of Health and Human Services. reported as $\mathrm{As}(\mathrm{V})$. Consequently, the sample collection protocol was modified mid-study, whereby, an additional replicate sample for As(III) determination on the raw (POE) well water was collected. Thereafter, instead of two sample replicates, As(III) determinations on raw POE well water were performed in triplicate. All samples for As(III) determinations on raw water were collected in triplicate during the 2001-2 sample period. Except where noted, the only arsenic determination on post-household filtration (POU) water was for filtered arsenic.

\section{Arsenic Sample Preparation and Preservation}

Sample preparation for arsenic analysis included acidification to $\mathrm{pH}<2$ (Ultrex, ultra-high-purity nitric acid $\left[\mathrm{HNO}_{3}\right]$, J.T. Baker Chemical Company, Phillipsburg, N.J.) for filtered arsenic sample analysis, and filtration through $0.45 \mu \mathrm{m}$ nylon syringe filters, followed by acidification ( 5 percent [volume per volume] sulfuric acid [0.05 percent ${ }_{\text {final }} \mathrm{H}_{2} \mathrm{SO}_{4}$ ], Baker Instra-Analyzed, J.T. Baker Chemical Company) for filtered arsenic sample analysis and arsenic speciation (valence) analysis. Samples for As(III) and $\mathrm{As}(\mathrm{V})$ analysis were prepared onsite by eluting aliquots of the filtered/acidified samples through anion-exchange chromatography columns according to the method described by Ficklin (1983). Once aliquots for arsenic valence analysis were collected, the samples for filtered arsenic analysis were further acidified to $\mathrm{pH}<2$ with $\mathrm{HNO}_{3}$ (Ultrex). This step was necessary to prevent $\mathrm{HNO}_{3}$ damage to the anion-exchange resin. The $\mathrm{H}_{2} \mathrm{SO}_{4}$ step was necessary to adjust the $\mathrm{pH}$ of the source water to approximately $\mathrm{pH}$ 4. At this $\mathrm{pH}$, the anion-exchange columns retain the negatively charged $\mathrm{As}(\mathrm{V})$ species while allowing the neutral As(III) species to pass through in the filtrate (Ficklin, 1983; Edwards and others, 1998; Wilkie and Hering, 1998). The filtrates were collected and further acidified to $\mathrm{pH}<2$ with $\mathrm{HNO}_{3}$. Any arsenic measured in these samples is interpreted to be As(III) (table 3). As(V) was determined as the difference between filtered arsenic and As(III). Total particulate arsenic was determined as the difference between unfiltered and filtered arsenic samples.

Arsenic analyses were performed by three laboratories: (1) the Maine Department of Human Services HETL, Augusta, Maine, (2) UL, South Bend, Ind., and (3) the USGS NWQL, Denver, Colorado (table 3). Interlaboratory comparisons are displayed in figures 2 and 3 and are available in the published data (Culbertson and others, 2020).

\section{Preparation of Field Anion-Exchange Chromatography Columns for Arsenic Speciation Analysis}

Anion-exchange chromatography columns for the separation of $\mathrm{As}(\mathrm{III})$ and $\mathrm{As}(\mathrm{V})$ in the field were prepared in the laboratory prior to well-water sample collection. AG 1 anion-exchange resin (50-100 mesh; Bio-Rad Laboratories, 

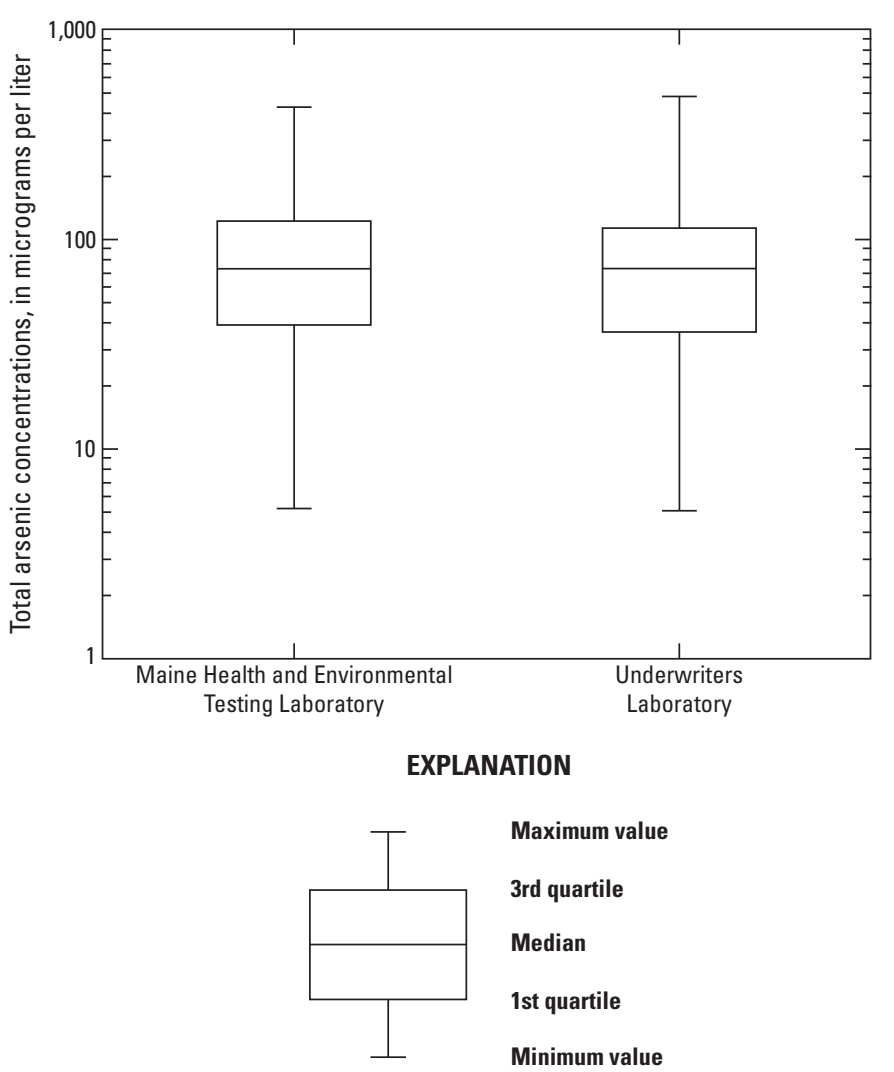

Figure 2. Distribution of unfiltered arsenic concentrations in paired samples analyzed by the Maine Department of Human Services Health and Environmental Testing Laboratory (HETL) and Underwriters Laboratories Inc. (UL), 2006-7. Modified from Nielsen and others (2010).

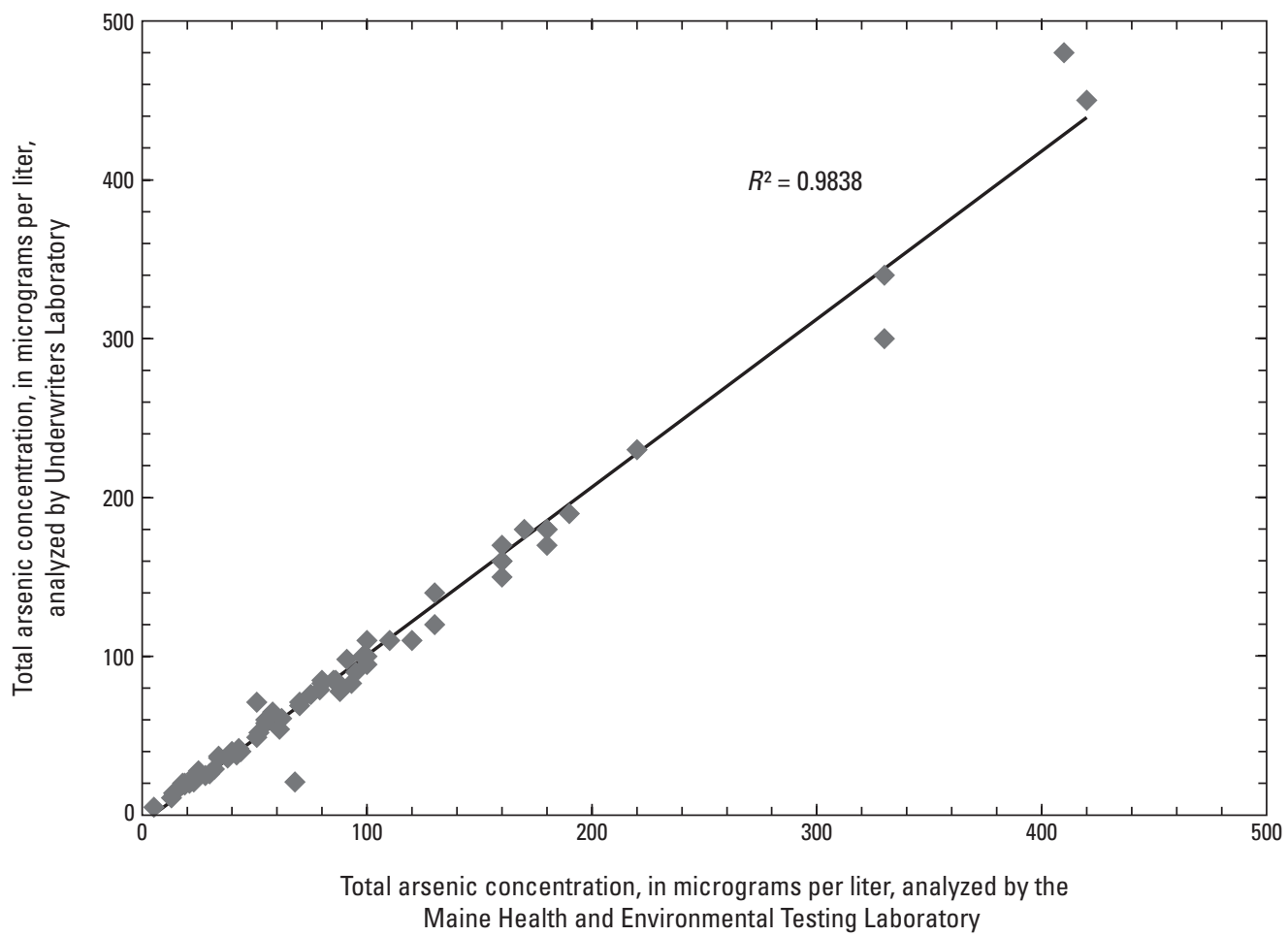

Hercules, Calif.) was obtained in the chloride form and converted to the acetate form prior to column packing (Wilkie and Hering, 1998). Poly-Prep 0.8 x 4-centimeter polypropylene chromatography columns (Bio-Rad Laboratories, Hercules, Calif.) were slurry-vibra-packed with approximately 2 milliliters of the converted anion-exchange resin and excess deionized water to keep the resin moist (vibra-packing of the resin slurry was used to eliminate channeling in the resin bed). Columns were capped and refrigerated until use in the field. The anion-exchange columns were prepared in batches of 100; column efficiency tests were performed on each batch. Representative anion-exchange column efficiencies are shown in tables 4 and 5 .

\section{Quality Assessment of Laboratory Arsenic Analysis}

Arsenic in all samples was determined by inductively coupled plasma-mass spectrometry (EPA Method 200.8; U.S. Environmental Protection Agency, 1994) by the HETL (table 1). As a QA check of samples analyzed by the HETL, replicate samples, collected during 2001-2, were analyzed for unfiltered arsenic by an alternate method: USGS Method GF096: "Arsenic Determination by Hydride Generation/ Atomic Absorption Spectrometry" by the USGS NWQL (table 1).

Figure 3. Arsenic concentrations in paired samples analyzed by the Maine Department of Human Services Health and Environmental Testing Laboratory and Underwriters Laboratories Inc., 2006-7. Modified from Nielsen and others (2010). 
Table 4. Representative efficiency of anion-exchange chromatography resin for the field separation of As(III) and As(V) for single arsenic species recovery.

[As, arsenic; $\mu \mathrm{g} / \mathrm{L}$, microgram per liter As(III), arsenic-3 or arsenite; As(V), arsenic-5 or arsenate]

\begin{tabular}{|c|c|c|}
\hline Replicate number & $\begin{array}{c}\text { As added } \\
(\mu \mathrm{g} / \mathrm{L})\end{array}$ & $\begin{array}{c}\text { As recoverable } \\
(\mu \mathrm{g} / \mathrm{L})\end{array}$ \\
\hline \multicolumn{3}{|c|}{ As(III) } \\
\hline Replicate 1 & 62 & 61 \\
\hline Replicate 2 & 62 & 61 \\
\hline Replicate 3 & 62 & 57 \\
\hline \multicolumn{3}{|c|}{$\mathrm{As}(\mathrm{V})$} \\
\hline Replicate 1 & 67 & $<0.5$ \\
\hline Replicate 2 & 67 & $<0.5$ \\
\hline Replicate 3 & 67 & $<0.5$ \\
\hline
\end{tabular}

Table 5. Representative efficiency of anion-exchange chromatography resin for the field separation of As(III) and As(V) for As(III)+As(V) mix recovery.

[As, arsenic; As(III), arsenic-3 or arsenite; $\mu \mathrm{g} / \mathrm{L}$, microgram per liter; $\mathrm{As}(\mathrm{V})$, arsenic-5 or arsenate]

\begin{tabular}{lccc}
\hline Replicate number & $\begin{array}{c}\text { As(III) added } \\
(\boldsymbol{\mu g} / \mathbf{L})\end{array}$ & $\begin{array}{c}\text { As(V) added } \\
(\boldsymbol{\mu g} / \mathbf{L})\end{array}$ & $\begin{array}{c}\text { As recoverable } \\
(\boldsymbol{\mu} \mathbf{g} / \mathbf{L})\end{array}$ \\
\hline Replicate 1 & 33 & 34 & 31 \\
Replicate 2 & 33 & 34 & 32 \\
\hline
\end{tabular}

An assessment of the HETL and UL arsenic analyses was derived from a 2006-7 comparison of arsenic determinations reported by each laboratory for replicate (paired) samples. Sixty-four samples from wells with concentrations of arsenic ranging from 5 to 420 micrograms per liter $(\mu \mathrm{g} / \mathrm{L})$ were replicated (sampled at the same time and from the same source, preserved in the same way, and analyzed by using EPA Method 200.8). The results of the analyses for unfiltered arsenic from the two laboratories were compared to assure quality in the analytical process (figs. 2 and 3; Nielsen and others, 2010; Culbertson and others, 2020).

In general, the average difference in concentration for the 64 sample pairs analyzed by HETL and UL, expressed as the absolute value of the relative percent difference between the samples, was about 7.6 percent $(\mid[\mathrm{HETL}-\mathrm{UL}] /([\mathrm{HETL}+\mathrm{UL}] / 2)$ *100). A comparison of concentrations for the paired samples (fig. 3) shows that, for the most part, this difference is primarily at the upper end of the range in concentrations of arsenic (with one exception at the lower end of the range). The range in relative percent difference is 0 to 105 percent, although only two samples have a relative percent difference greater than 16.7 percent. According to a one-way analysis of variance of the datasets, the concentration means are not significantly different at the $p=0.05$ level (Nielsen and others, 2010).

\section{References Cited}

American Public Health Association, 1998, Standard methods for the examination of water and wastewater (20th ed.): Washington, D.C., American Public Health Association, American Water Works Association, and Water Environment Federation, 1,325 p.

Ayotte, J.D., Montgomery, D.L., Flanagan, S.M., and Robinson, K.W., 2003, Arsenic in groundwater in eastern New England-Occurrence, controls, and human health implications: Environmental Science \& Technology, v. 37, no. 10 , p. 2075-2083.

Ayotte, J.D., Nielsen, M.G., Robinson, G.R., and Moore, R.B., 1999, Relation of arsenic, iron, and manganese in ground water to aquifer type, bedrock lithogeochemistry, and land use in the New England Coastal Basins Study Unit: U.S. Geological Survey Water-Resources Investigations Report 99-4162, $61 \mathrm{p}$.

Ayotte, J.D., Nolan, B.T., Nuckols, J.R., Cantor, K.P., Robinson, G.R., Jr., Baris, D., Hayes, L., Karagas, M.R., Bress, W., Silverman, D.T., and Lubin, J.H., 2006, Modeling the probability of arsenic in groundwater in New England as a tool for exposure assessment: Environmental Science \& Technology, v. 40, no. 11, p. 3578-3585.

Culbertson, C.W., Caldwell, J.M., Schalk, L.F., and Medalie, L., 2020, Arsenic datasets and other physical and chemical measurements for selected domestic well-water supplies in Maine-2001-2 and 2006-7: U.S. Geological Survey data release, https://doi.org/10.5066/P9X5HVDF.

Cullen, W.R., and Reimer, K.J., 1989, Arsenic speciation in the environment: Chemical Reviews, v. 89, no. 4, p. 713-764.

DeSimone, L.A., Hamilton, P.A., and Gilliom, R.J., 2009, Quality of water from domestic wells in principal aquifers of the United States, 1991-2004-Overview of major findings: U.S. Geological Survey Circular 1332, 48 p.

Edwards, M., Patel, S., McNeill, L., Chen, H., Frey, M., Eaton, A.D., Antweiler, R.C., and Taylor, H.E., 1998, Considerations in As analysis and speciation: Journal American Water Works Association, v. 90, no. 3, p. 103-113.

Ficklin, W.H., 1983, Separation of arsenic(III) and arsenic(V) in ground waters by ion-exchange: Talanta, v. 30, no. 5, p. 371-373.

Flanagan, S.M., Ayotte, J.D., and Robinson, G.R., Jr., 2012, Quality of water from crystalline rock aquifers in New England, New Jersey, and New York, 1995-2007 (ver. 1.1, April 2018): U.S. Geological Survey Scientific Investigations Report 2011-5220, 104 p., accessed October 29, 2019, at https://doi.org/10.3133/sir20115220. 
Focazio, M.J., Welch, A.H., Watkins, S.A., Helsel, D.R., and Horn, M.A., 2000, A retrospective analysis on the occurrence of arsenic in ground-water resources of the United States and limitations in drinking-water-supply characterizations: U.S. Geological Survey Water-Resources Investigations Report 99-4279, 21 p.

Fravel, H.G., Jr., and Lindsey, K., 2014, Understanding salt passage vs. salt rejection in reverse osmosis systems: American Membrane Technology Association blog, August 29, 2014, accessed August 2017 at https://www.amtaorg.com/understanding-salt-passage-vssalt-rejection-in-reverse-osmosis-systems.

Hach Company, 2000, Procedures manual, DR2010/DR2400 Spectrophotometer (7th ed., October 2000): Loveland, Colo., Hach Company, 872 p.

Korte, N.E., and Fernando, Q., 1991, A review of arsenic (III) in groundwater: Critical Reviews in Environmental Science and Technology, v. 21, no. 1, p. 1-39.

Lipfert, G., Reeve, A.S., Sidle, W.C., and Marvinney, R.G., 2006, Geochemical patterns of arsenic-enriched ground water in fractured crystalline bedrock, Northport, Maine, USA: Applied Geochemistry, v. 21, no. 3, p. 528-545.

Marvinney, R.G., Loiselle, M.C., Hopeck, J.T., Braley, D., and Krueger, J.A., 1994, Arsenic in Maine ground water-An example from Buxton, Maine, in Proceedings of the 1994 Focus Conference on Eastern Regional Ground Water Issues, Burlington, Vt., October 3-5: National Ground Water Association, p. 701-715.

Marvinney, R.G., Loiselle, M.C., Hopeck, J.T., Braley, D., and Krueger, J.A., 1995, Arsenic in Maine groundwater-An example from Buxton, Maine [abs.]: Geological Society of America Abstracts with Programs, v. 27, p. 67.

National Research Council, 1999, Arsenic in drinking water: Washington, D.C., National Academy Press, 330 p.

National Research Council, 2001, Arsenic in drinking water-2001 update: Washington, D.C., National Academy Press, $244 \mathrm{p}$.

Nielsen, M.G., Lombard, P.J., and Schalk, L.F., 2010, Assessment of arsenic concentrations in domestic well water, by town, in Maine, 2005-09: U.S. Geological Survey Scientific Investigations Report 2010-5199, 68 p. [Also available at https://doi.org/10.3133/sir20105199.]

Peters, S.C., Blum, J.D., Klaue, B., and Karagas, M.R., 1999, Arsenic occurrence in New Hampshire drinking water: Environmental Science \& Technology, v. 33, no. 9, p. $1328-1333$.

Ryker, S.J., 2001, Mapping arsenic in ground water: Geotimes, v. 46 , no. 11, p. $34-36$.
Shapiro, S.S., and Francia, R.S., 1972, An approximate analysis of variance test for normality: Journal of the American Statistical Association, v. 67, no. 337, p. 215-216.

Smedley, P.L., and Kinniburgh, D.G., 2002, A review of the source, behavior and distribution of arsenic in natural waters: Applied Geochemistry, v. 17, no. 5, p. 517-568.

U.S. Environmental Protection Agency, 1994, Method 200.8Determination of trace elements in waters and wastes by inductively coupled plasma-mass spectrometry (rev. 5.4): U.S. Environmental Protection Agency method, 57 p.

U.S. Environmental Protection Agency, 2001, National primary drinking water regulations-Arsenic and clarifications to compliance and new source contaminants monitoring [final rule]: Federal Register, v. 66, no. 14, p. 6975-7066.

U.S. Geological Survey, 2019, USGS water data for the Nation: U.S. Geological Survey National Water Information System database, accessed May 14, 2019, at https://doi.org/ 10.5066/F7P55KJN.

U.S. Geological Survey, [variously dated], National field manual for the collection of water-quality data: U.S. Geological Survey Techniques of Water-Resources Investigations, book 9, chaps. A1-A10, accessed April 4, 2017, at https://pubs.water.usgs.gov/twri9A.

Welch, A.H., Helsel, D.R., Focazio, M.J., and Watkins, S.A., 1999, Arsenic in ground water supplies of the United States, in Chappell, W.R., Abernathy, C.O., and Calderon, R.L., eds., Arsenic exposure and health effects: Burlington, Mass., Elsevier, p. 9-17.

Welch, A.H., Westjohn, D.B., Helsel, D.R., and Wanty, R.B., 2000, Arsenic in ground water of the United StatesOccurrence and geochemistry: Ground Water, v. 38, no. 4, p. 589-604.

Wilkie, J.A., and Hering, J.G., 1998, Rapid oxidation of geothermal arsenic(III) in streamwaters of the Eastern Sierra Nevada: Environmental Science \& Technology, v. 32, no. 5, p. 657-662.

Yang, Q., Jung, H.B., Culbertson, C.W., Marvinney, R.G., Loiselle, M.C., Locke, D.B., Cheek, H., Thibodeau, H., and Zheng, Y., 2009, Spatial pattern of groundwater arsenic occurrence and association with bedrock geology in greater Augusta, Maine, USA: Environmental Science \& Technology, v. 43, no. 8, p. 2714-2719.

Zheng, Y., and Ayotte, J.D., 2015, At the crossroads-Hazard assessment and reduction of health risks from arsenic in private well waters of the northeastern United States and Atlantic Canada: Science of the Total Environment, v. 505, p. $1237-1247$. 

For more information about this report, contact: Director, New England Water Science Center U.S. Geological Survey 10 Bearfoot Road

Northborough, MA 01532

dc_nweng@usgs.gov or visit our website at https://www.usgs.gov/centers/new-england-water

Publishing support provided by the Pembroke and Rolla Publishing Service Centers 


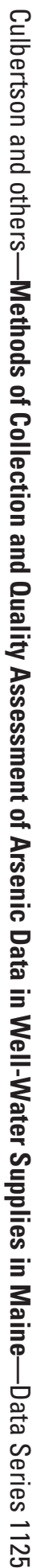

